\title{
Tending operation models for white poplar (Populus alba L.) stands growing under sandy soil conditions
}

\author{
Rédei, K. ${ }^{1}$, Keserü, Zs. ${ }^{1}$, Orlovic, S. $^{2}$ \& Galic, $Z_{.}^{2}$ \\ ${ }^{1}$ Forest research Institute, H-9600 Sárvár, Hungary \\ ${ }^{2}$ Institute of Lowland Forestry and Environment, SR-21000 Novi Sad, Serbia E-mail:redei.karoly@ t-online.hu
}

\begin{abstract}
Summary: Integrated research aimed to intensify the practices of afforestation especially of white poplar and grey poplar woods. A new, simplified tending procedure has been developed to substitute earlier models considering the target diameter by right spacing as a tool to achieve adequat quality of logs. The practice-oriented model may help the qualitative improvement of white poplar growing technology in Hungary as well as in Serbia.
\end{abstract}

Key words: white poplar (Populus alba L.), tending operations, growing models

\section{Introduction}

White poplar (Populus alba L.) and its most important natural hybrid, the grey poplar (Populus x canescens), are native tree species in Hungary (Szodfridt- Palotás, 1973; Tóth B. (edit.),1996; Rédei, 1991) and is Serbia (Guzina, Bozic, 1984; Guzina (edit.), 1986). Due to their favourable silvicultural and growth characteristics, as well as the possibilities for the utilisation of their wood, the area they occupy is increasing continuously. The most important task facing Hungarian and Serbian poplar growers is improving the quality and increasing the quantity of poplar stands for wood production (Pletikapic-Kolevska, 1985; Rédei, 2000; Orlovic-Kovacevic - Pilipovic - Galic, 2003,).

The main economic purpose of plantation forestry is to increase the level of timber production to a degree on which the given sized area and within the limits set by ecological conditions provides the biggest yield and consequently provides the biggest earnings within the shortest period of time, whilst keeping investment and risk are at the lowest possible minimum.

The most important characteristics of plantation forestry can be summed up as follows (Führer-Rédei-Tóth, 2009.):

- the production of target sortiments defined in advance in huge quantities and the same quality,

- the application of a relatively closed growing-technology system from forestation to final cutting, of which agricultural intensiveness is partly also a characteristic of (e.g. fast-growing tree species, respectively the monocultures, intensive pruning system, etc.) furthermore

- the renovation of forest stands is only possible in an artificial manner.

Apart from the poplar species to be used for plantation forestry black locust, red oak and black walnut can also be suitable for this type of forest management. Common walnut plantations can be listed here too, but the sylvicultural significance of this tree species is negligible.

From among the above listed tree species the models for tending operations and the tables for age-growth space-target diameter models are suitable for production of large, quality wood material as well as mass sortiments produced in white poplar stands.

\section{Simplified tending operation model for white poplar stands}

White poplar is a fast-growing species. Seedlings quickly emerge from the phase of competition with weeds. In-line and inter-row weeding is required in the first years of plantations established by means of seeding, as is the removal of failed plants. During tending operations it is important to take into consideration the fact that plantations consist of trees of varied genetic make-up (genotype). In terms of the demand for light, it is worth remembering that while poplar reacts extremely strongly to light availability, it also tolerates shade very well.

Table 1. contains a simplified tending operation model for white poplar, for its compilation we used the data of 70 long term expiry yield and experimental tending operation plots. To choose the must suitable planting spacing, it depends on the quality of the planting material and the particular site conditions. The tending cuttings (growth space expansions) must be carried out when the stem number approximately aproaches the stem data contained in the table prior to the tending cuttings.

In case of plantations planted in a planting spacing of $3 \times 3$ $\mathrm{m}$ or $3 \times 2 \mathrm{~m}$, there is no need for cleaning, except if the 
saplings are not steady of growth. In case of the initial spacing narrower than that of $3 \times 1 \mathrm{~m}$ or $2.5 \times 1 \mathrm{~m}$, in plantations established with white poplar clones one, respectively two growing space cleanings are recommended.

\begin{tabular}{|c|c|c|c|c|c|c|}
\hline \multirow{3}{*}{$\begin{array}{c}\text { Tending } \\
\text { operation }\end{array}$} & \multirow{3}{*}{ Number } & \multicolumn{3}{|c|}{ The improvement cutting } & \multicolumn{2}{|c|}{ Stem number (pc/acs) } \\
\hline & & \multirow{2}{*}{$\begin{array}{c}\text { Year to } \\
\text { be } \\
\text { carried } \\
\text { out at } \\
\text { (age) } \\
\text { (year) }\end{array}$} & \multirow{2}{*}{\multicolumn{2}{|c|}{$\begin{array}{l}\text { At the time of } \\
\mathbf{H}_{\mathrm{m}}(\mathrm{m}) \text { and } \\
\text { Yield class }\end{array}$}} & \multicolumn{2}{|c|}{$\begin{array}{l}\text { the improvement } \\
\text { cutting }\end{array}$} \\
\hline & & & & & Before & after \\
\hline \multirow{2}{*}{ Cleaning } & \multirow{2}{*}{$\begin{array}{l}1 . \\
2 .\end{array}$} & \multirow{2}{*}{$\begin{array}{c}5-10 \\
11-14\end{array}$} & 6 & $(\mathrm{I}-\mathrm{VI})$. & \multirow{2}{*}{$\begin{array}{c}>3000 \\
3000\end{array}$} & \multirow{2}{*}{$\begin{array}{c}3000 \\
1300-1800\end{array}$} \\
\hline & & & $8-11$ & $(\mathrm{I}-\mathrm{VI})$. & & \\
\hline \multirow{2}{*}{ Thinning } & \multirow{2}{*}{$\begin{array}{l}1 . \\
2 .\end{array}$} & \multirow{2}{*}{$\begin{array}{l}15-20 \\
21-25\end{array}$} & $12-17$ & $(\mathrm{I}-\mathrm{V})$. & \multirow{2}{*}{$\mid \begin{array}{c}1300-1800 \\
650-1200\end{array}$} & \multirow{2}{*}{$\begin{array}{c}650-1200 \\
350-600\end{array}$} \\
\hline & & & $16-23$ & (I-IV.) & & \\
\hline \multirow{2}{*}{$\begin{array}{c}\text { Final } \\
\text { cutting }\end{array}$} & & $\begin{array}{c}40 \\
30-35\end{array}$ & & \begin{tabular}{|c|} 
(I-II.) \\
(III-IV.)
\end{tabular} & & $\begin{array}{l}350-400 \\
500-600\end{array}$ \\
\hline & & $\begin{array}{l}25-30 \\
20-25\end{array}$ & & $\begin{array}{l}\text { (V.) } \\
\text { (VI.) }\end{array}$ & & \begin{tabular}{|c|}
$800-900$ \\
$1000-1100$
\end{tabular} \\
\hline
\end{tabular}

\section{Remarks for the use of the tending model:}

During the planning of thinnings, the better the estimated yield class is, the more the lower value of the stem numbers after the tending cutting must be approached.

The white poplars stands in yield classes V-VI. do not make for quality wood production.

\section{Age - growing space - target diameter models for white poplar stands}

In plantation forestry, the timing of the growing space expansion has a stressed significance for reaching the given target sortiment production by maintenance of the near optimal stem number per hectar (growth space). The site (ecological) factors define basicly the target sortiments, e.g. whether there is an opportunity for the production of sizeable, quality wood material (panel log, sawlog) or just thinner sized, so-called mass wood sortiments (cutting, pallet and box basic material) paper wood, wood fibre, chippings as well as wooden board basic materials can be produced.

The basic coherence pertaining to the growth spacemodelling of the white poplar stands can be demonstrated by the following equation:

$$
\mathrm{N}=\mathrm{e}^{8.75483-0.838791 \mathrm{nD}} 1.3
$$

where: $\mathrm{N}=$ stem number of the remaining stand on 1 hectare, $\mathrm{D}_{1.3}=$ diameter at breast height (in $\mathrm{cm}$ ).
The data in Table 2 show that a decisive opportunity for quality, sizeable log production can be available in the white poplar stands classified in yield class I-III. In the white poplar stands in yield class IV - taking the average cutting age of 30 years into account - a target diameter of 18 and 20 $\mathrm{cm}$ can be planned with great certainty. The sustainable stem number per 1 hectare depending on the yield class varies between 320 to 560 pieces.

Table 2. Age-target diameter model for white poplar stand suited for quality $\log$ production

\begin{tabular}{|c|c|c|c|}
\hline \multirow[b]{2}{*}{$\begin{array}{l}\text { Planned target } \\
\text { diameter }\left(\mathrm{D}_{1.3}\right) \\
(\mathrm{cm})\end{array}$} & \multicolumn{3}{|c|}{ Factors } \\
\hline & Yield class & $\begin{array}{c}\text { The age (year) } \\
\text { necessary for reaching } \\
\text { the given diameter } \\
\left(D_{1.3}\right)\end{array}$ & $\begin{array}{c}\text { Stem number } \\
\text { (N) 1-hectare } \\
\text { (pc/ha) }\end{array}$ \\
\hline 18 & I. & 14 & \multirow{4}{*}{$560 \pm 5 \%$} \\
\hline 18 & II. & 17 & \\
\hline 18 & III. & 21 & \\
\hline 18 & IV. & 28 & \\
\hline 20 & I. & 16 & \multirow{4}{*}{$515 \pm 5 \%$} \\
\hline 20 & II. & 18 & \\
\hline 20 & III & 23 & \\
\hline 20 & IV. & 32 & \\
\hline 25 & I. & 21 & \multirow{3}{*}{$425 \pm 5 \%$} \\
\hline 25 & II. & 25 & \\
\hline 25 & III. & 37 & \\
\hline 30 & I. & 28 & \multirow{2}{*}{$365 \pm 5 \%$} \\
\hline 30 & II. & 42 & \\
\hline 35 & I. & 43 & $320 \pm 5 \%$ \\
\hline
\end{tabular}

Table 3. Age-target diameter model white poplar stands suitable for production of mass sortiments

\begin{tabular}{|c|c|c|c|}
\hline \multirow[b]{2}{*}{$\begin{array}{l}\text { Planned target } \\
\text { diameter } \mathrm{D}_{1.3} \\
(\mathrm{~cm})\end{array}$} & \multicolumn{3}{|c|}{ Factors } \\
\hline & Yield class & $\begin{array}{c}\text { The age (year) } \\
\text { necessary for reaching } \\
\text { the given diameter } \\
\left(D_{1.3}\right)\end{array}$ & $\begin{array}{l}\text { Stem number } \\
\text { (N) per } \\
\text { 1-hectare } \\
\text { (pc/ha) }\end{array}$ \\
\hline 10 & IV. & 11 & \multirow{3}{*}{$920 \pm 5 \%$} \\
\hline 10 & V. & 14 & \\
\hline 10 & VI. & 19 & \\
\hline 12 & IV. & 13 & \multirow{3}{*}{$790 \pm 5 \%$} \\
\hline 12 & V. & 17 & \\
\hline 12 & VI. & 25 & \\
\hline 14 & IV. & 15 & \multirow{3}{*}{$690 \pm 5 \%$} \\
\hline 14 & V. & 24 & \\
\hline 14 & VI. & - & \\
\hline 16 & IV. & 20 & \multirow{3}{*}{$620 \pm 5 \%$} \\
\hline 16 & V. & 31 & \\
\hline 16 & VI. & - & \\
\hline
\end{tabular}


The Table 3 shows that for the production of mass sortiments in stands of IV, $V$ yield class and eventually in case of a plannable 10-12 cm target diameter even the white poplars in yield class VI may be suitable.

At the same time in these two latter yield classes, the stands are usually less producing in most case, so these cannot be the subjects of plantation forestry.

In the white poplar stands produced under worse ecological conditions the plannable final-cutting age is also shorter (generally between 25-30 years). The sustainable stem number varies between 620-920 pc/ha depending on the yield class. In these white poplar stands - based on our yield studies - the stem number reduction (thinning) carried out after age 15-17 does not produce significant diameter growth surplus either.

\section{Conclusions}

The growing-improvement of plantation-like white poplar management is becoming ever more significant with regard to lowland forestry. This study has also been prepared by taking this fact into account, and by making the novel planning accessories which help advance the increase of value output of the wood material produceable in white poplar stands. We hope that the published models will prove useful for the practice in Hungary and also in Serbia.

\section{Acknowledgements}

Research on white poplar improvement in partly supported by the called Hungarian-Serbian bilateral cooperation (project number: RS-6/2009, Tét Fundation) and Kiskunsági Forest and Wood Processing Share Company (KEFAG ZRt., Kecskemét).

\section{References}

Führer, E., Rédei, K. \& Tóth, B. (2009): Ültetvényszerü fatermesztés 1. (Plantation Forestry 1.) Agroinform Kiadó, Bp. 108-125.

Guzina, V. (edit.) (1986): Poplars and willows in Yugoslavia. Forest Research Institute, Novi Sad.

Guzina, V. \& Bozic J. (1984): Oplemenjivanje topola sekcije Leuce Duby i mogucnost njihovog koriscenja za proizvodnju celuloze i papira. 141-142:. 55-64.

Orlovic. S., Kovacevic, B., Pilipovic, A. \& Galic, Z. (2003): Selekcija i hibridizacija topola iz sekcije Leuce Duby. Radovi Knjiga 25: 15-27.

Pletikapic-Kolevska, B. (1985): Klonsko razmnozavanje Leuce topola metodom kulture tkiva. Topola 145-46:. 3-9.

Rédei, K. (1991): Improvement of Leuce-poplars growing in Hungary. Erdészeti Kutatások, 82-83: 304-312.

Rédei, K. (2000): Early performance of promising white Poplar (Populus al ba) clones in sandy ridges between the rivers Danube and Tisza in Hungary. Forestry, 73, 4: 407-413.

Szodfridt, I. \& Palotás, F. (1973): Hazai nyárak. (Native poplars). [In Danszky.I. (edit.): Erdőmüvelés II. (Silviculture II).] Mezőgazdasági Kiadó. Budapest. (in Hungarian).

Tóth, B. (edit.) (1996): Poplar and willow growing in Hungary. Forest Research Institute, Budapest. 